Dariusz Kubok

Uniwersytet Śląski, Katowice

e-mail: dariusz.kubok@us.edu.pl

\title{
Poza Skyllą i Charybdą. Problem fallibilistycznej wykładni poglądów Ksenofanesa
}

DOI: http://dx.doi.org/10.12775/RF.2017.036

Przy próbie zdefiniowania fallibilizmu często można natrafić na sformułowanie, że stanowisko to jest trzecią drogą między dogmatyzmem a sceptycyzmem. Niektórzy badacze sugestywnie opisują ją jako drogę pomiędzy Skyllą $(\Sigma \kappa u ́ \lambda \lambda \eta)$ a Charybdą (Xó $\varrho u \beta \delta ı \varsigma)$, która jest alternatywą wobec skrajności tamtych doktryn ${ }^{1}$. Więcej nawet, opowiadanie się za fallibilizmem wymaga umiejętności odpowiedniej nawigacji pomiędzy Skyllą jako skałą dogmatyzmu (fundamentalizmu epistemologicznego) a Charybdą jako wirem sceptycyzmu rozumianego współcześnie jako agnostycyzm $\mathrm{w}$ formule negatywnego dogmatyzmu². Fallibilista stara się nie rozbić o skałę dogmatyzmu ani nie dać się wchłonąć wirowi negatywnego dogmatyzmu. $W$ tym sensie fallibilizm jest jednym ze stanowisk antydogmatycznych, przeciwstawia się zarazem pozytywnemu dogmatyzmowi, jak i negatywnemu dogmatyzmowi. W niniejszym

1 "Fallibilism is an attractive epistemological position, avoiding the Scylla of rationalism, and the Charibdis of scepticism, and acknowledging on the one hand, human imperfection, yet claiming that science and rational inquiry are possible". R. Weintraub, Fallibilism and Rational Belief, "The British Journal for the Philosophy of Science" 1993, vol. 44, iss. 2, s. 251.

2 "Agnostycyzm to negatywny dogmatyzm w postaci tezy o niepoznawalności [...]. Dziś, kiedy sceptycyzm interpretujemy jako tezę, WIEDZA NIE ISTNIEJE, różnica pomiędzy sceptycyzmem i agnostycyzmem (świat jest niepoznawalny) zaciera się i może być tylko różnicą stopnia i aspektu. Agnostycyzm brzmi jako teza mocniejsza i bardziej zdecydowana. Sceptycyzm natomiast ma wpisane wątpienie we własną tezę. Agnostycyzm stał się współcześnie synonimem sceptycyzmu lub sceptycyzmem bardziej stanowczym". R. Ziemińska, Historia sceptycyzmu, Torun 2013, s. 35. 
artykule postaram się pokazać zarówno trudności, jak i możliwości fallibilistycznego odczytania poglądów Ksenofanesa. Trzeba bowiem w tym wypadku również uważać, aby z jednej strony nie rozbić się o dogmatyczne imputowanie Grekom stanowiska fallibilistycznego, a z drugiej nie wykluczać wszelkich greckich antecedencji współczesnych koncep$\mathrm{cji}^{3}$.

\section{Cieśnina Skylli i Charybdy oraz inna droga}

Eksploatując nadal metaforę podróży Odyseusza, warto sięgnąć do szerszego kontekstu opowieści o Skylli i Charybdzie. Okazuje się, że istnieje inna droga niż ta przez cieśninę, przy której siedziby mają oba te potwory; jest zatem alternatywa dla wspomnianej wyżej drogi. Z tego wynika, że nie chodzi o to, jak znaleźć drogę (jak nawigować) pomiędzy Skyllą a Charybda, lecz czy da się odszukać drogę poza nimi. Kluczową sprawą jest zdanie sobie sprawy, że nie ma jakiejś domniemanej trzeciej drogi pomiędzy Skyllą a Charybdą ponieważ nie ma żadnego "pomiędzy” w odniesieniu do pozytywnego dogmatyzmu i negatywnego dogmaty$\mathrm{zmu}$; tertium non datur. Jeśli istnieje jakaś inna możliwość, nie zakładająca de facto tertium datur, to znajduje się poza tym, co dane. Powstaje pytanie, czy istnieje inna droga niż ta przez cieśninę okupowaną przez Skyllę i Charybdę. Stosowną odpowiedź można znaleźć u Homera (Odyseja, XII, 55-72), we fragmencie poprzedzającym opowieść o potworach. Kirke zwraca się do Odyseusza, mówiąc mu, że nie wskaże mu właściwej drogi, ale tylko zaprezentuje dwie możliwe drogi żeglugi:

(1) pierwsza przez wody, gdzie znajdują się "błądzące skały" ( $\pi \lambda \alpha \gamma \kappa \tau \alpha \grave{\imath} \pi \varepsilon ́ \tau \varrho \alpha \iota)$.

(2) druga przez wspomnianą cieśninę, przy której czyhają Skylla i Charybda .

3 Opowieść o obu tych potworach morskich (Homer, Odyseja, XII, 73-100) może dobrze opisywać metaforycznie dwie tendencje traktowania przeszłości filozoficznej, w tym: filozofów greckich. Podejście skylliczne charakteryzuje się tendencją do imputowania wybranym historycznym myślicielom lub doktrynom późniejszych koncepcji, po czym zwrotnie - z mniejszym lub większym zdziwieniem - odkrywa się, że poglądy tych myślicieli są prekursorskie w zakresie głoszonych przez siebie poglądów. Skylla - jak wiadomo - lubiła porywać żeglarzy z okrętów jedną ze swoich ohydnych paszcz. Rozwijając tę metaforę w perspektywie podejścia skyllicznego, można by powiedzieć, że ci porwani żeglarze zostają z powrotem wypluci na pokład historii filozofii. Z kolei podejście charybdowe zakłada niedostrzeganie niewidocznego wiru, który determinuje żeglugę i choć stanowi potencjalne zagrożenie, to tylko trzy razy na dobę ujawnia swą moc. W tym przypadku nie widzi się lub nie chce się dostrzegać w dziejach ludzkiej myśli źródeł współczesnych poglądów.

4 Badacze wskazują na paralele pomiędzy tym fragmentem Odysei a fragm. DK 28 B 2 Parmenidesa. Zob. Die Fragmente der Vorsokratiker. Griechisch und Deutch von 
Co znamienne, Kirke ukazuje tylko istniejące możliwości pod postacią dwóch dróg, namawia jednak Odyseusza do tego, aby sam rozważył, która z nich jest lepsza. Warto nadmienić, że pierwsza droga zostaje opisana jako niesłychanie trudna i przerażająca do tego stopnia, że - jak pisze Homer - nikt się tędy nie przeprawił; ale, jak się okazuje, nie do końca, ponieważ udało się to okrętowi Argo przy pomocy bóstw. Z kolei trudności związane z drugą drogą wiążą się z wspomnianymi już Skyllą i Charybdą pomiędzy którymi ona przebiega.

Wybór dokonany przez Odyseusza jest wyborem greckiej filozofii, a w znacznym stopniu w ogóle filozofii na wiele wieków; to za nim podążały tabuny myślicieli, wpadając na skałę pozytywnego dogmatyzmu (uosabianą przez Skyllę) albo w wir agnostycyzmu jako negatywnego dogmatyzmu (uosabianą przez Charybdę), czy też próbując ostrożnie nawigować pomiędzy nimi; czyniąc to jednak, nadal tkwiło się w wyborze Odyseusza, nadal podążało się jego drogą. Przez bardzo długi czas nikt nie chciał iść pierwszą z wyróżnionych przez Kirke dróg. Wygląda na to, że wszyscy bardziej niż Skylli i Charybdy bali się „błądzących skał”

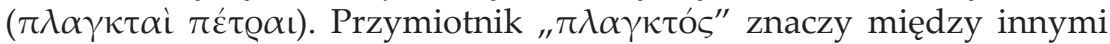
"błąkający się", "błądzący”, ,tułaczy” i został znamiennie wykorzystany przez Parmenidesa we frazie " $\pi \lambda \alpha \kappa \tau$ òv vóov" $\left(28\right.$ B 6, 6) ${ }^{5}$ na oznaczenie błądzącego myślenia przynależnego drodze mniemań. Błądzenie związane jest z omylnościa, ale - co ważne w kontekście interpretacji myśli greckiej - nie jest tożsame z fałszywością aktualną, tylko z potencjalną. Droga przez cieśninę Skylli i Charybdy jest przede wszystkim filozoficzną drogą zakładającą i operującą $w$ ramach modelu wiedzy typu

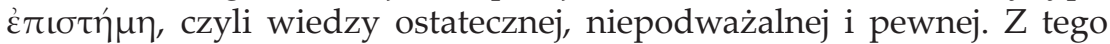
względu nawet sceptycy greccy wpisują się w model tej drogi, nierzadko sytuując swoje stanowisko de facto jako wir Charybdy lub - w słabszej wersji - jako mniej lub bardziej (koncepcja słabej asercji) zasadna (wiarygodna dla podmiotu) podróż pomiędzy owymi dwoma zagrożeniami. Długo nieuczęszczana droga pierwsza kwestionuje ten model wiedzy

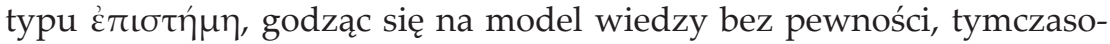
wej (a nie ostatecznej) i hipotetycznej (potencjalnie fałszywej). Taką propozycją jest fallibilizm. Zarysowany powyżej obraz wywodzący się od Homera pokazuje przy okazji dobrze dwie rzeczy. Po pierwsze, że oba stwory leżą przy tej samej cieśninie, to znaczy pozytywny dogmatyzm

H. Diels, hrsg. von W. Kranz, Bd. 1 - 3, Zürich 1985 (dalej cyt. jako DK). Wyraźna jest również analogia pomiędzy boginią i parmenidesowym koṽoos z jednej strony a Kirke i Odyseuszem z drugiej. Zob. E. A. Havelock, Parmenides and Odysseus, „Harvard Studies in Classical Philology" 1958, vol. 63, s. 133-143, A. P.D. Mourelatos, The Route of Parmenides, New Haven and London: Yale University Press 1970, s. 24-25.

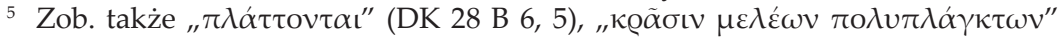
(DK 28 B 16, 1). 
i negatywny dogmatyzm jako agnostycyzm „operują" w obrębie tego

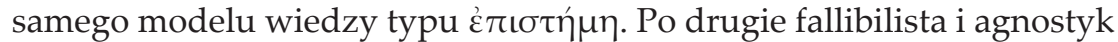
(negatywny dogmatyk, współcześnie również sceptyk głoszący, że wiedza nie istnieje) nie płyną w ogóle tymi samymi drogami; podobieństwa pomiędzy nimi, choć nie są pozorne, bledną w obliczu uświadomienia sobie, że ich kursy nie przecinają się ani nie są nakierowane na ten sam cel.

Nadmieniłem już, że tradycja filozoficzna, począwszy od Greków, poszła za wyborem Odyseusza, ale trzeba pamiętać, że Homer wspomina o okręcie Argo, któremu udało się przejść błądzące skały. Filozoficznie rzecz biorąc, powstaje pytanie, czy przed uformowaniem się modelu

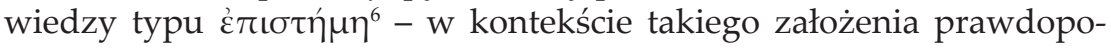
dobieństwo wzrasta - istniały jakieś poglądy, które można uznać za fallibilistyczne lub - ewentualnie - za choćby częściowe antecedencje fallibilizmu. Największe nadzieje związane z taką hipotezą łączą się z poglądami Ksenofanesa ${ }^{7}$. Pytanie postawione $w$ tym artykule brzmi: Czy myśliciel ten był fallibilistycznym argonauta, to znaczy, czy można uznać jego poglądy za antecedencje doktryny fallibilizmu.

\section{Niebo fallibilizmu i fallibilizm jako rodzina}

Fallibilizm jest współcześnie stanowiskiem obficie analizowanym, a jednocześnie dalekim od precyzyjnego zdefiniowania. Na bardzo ogólnym poziomie fallibilizm jest pojmowany jako koncepcja epistemologiczna akceptująca omylność i błądzenie, ale $\mathrm{w}$ takim przypadku definicja taka byłaby zbyt szeroka; pod takim „niebem fallibilizmu” mieściliby się nie tylko Peirce, Popper, czy Albert, ale także myśliciele dość odlegli od siebie w przekonaniach, jak Carnap i dajmy na to Rorty ${ }^{8}$. Nie zamierzam podawać ścisłej definicji tego stanowiska, czy też doktryny, zresztą sam fallibilizm nie wymaga rozstrzygających definicji. Wskażę tylko na określony „rdzeń znaczeniowy” fallibilizmu, ujawniający się w aspekcie negatywnym i pozytywnym, aby następnie rozważyć potencjalną obecność fallibilizmu i jego zakres w poglądach Ksenofanesa. Próbując rozpoznać antecedencje fallibilizmu, warto nie tylko krytycznie prze-

6 Nie wchodząc w szczegóły, można powiedzieć, że model ten jest trwale obecny w dziejach filozofii od czasów Platona i Arystotelesa, przy czym źródła tej koncepcji wiedzy tkwią w myśli przedplatońskiej (Heraklit, Parmenides, pitagorejczycy).

7 Warto by w drugiej kolejności rozważyć status drogi mniemań w filozofii Parmenidesa (28 B 1, 30-32; B 2, 5-8; B 6; B 7; B 8, 51-61; B 9; B 19).

8 Zob. S. Hanuszewicz, Znaczenie fallibilizmu, s. 140-205, http://zbc.uz.zgora.pl/ Content/3012/ fallibilizm_calosc.pdf, data wejścia: 29.11.2017. Autor omawia tam koncepcje fallibilistyczne, dzieląc je na klasyczny fallibilizm (Peirce, Popper, Lakatos, Albert) i nieklasyczny fallibilizm (Carnap, Rescher, Quine, Kuhn, Feyerabend, Rorty). 
analizować stanowiska wybranych sceptyków (akademików) pod tym kątem (podejście takie jest najczęstsze w literaturze), ale także cofnąć się do filozofii przedplatońskiej. Jest to o tyle uzasadnione, że we wczesnym okresie rozwoju filozofii - podkreślmy to jeszcze raz - nie był jeszcze ukształtowany (lub ukształtowany w pełni) model wiedzy w standardzie غ̇ंı alnych antecedencji fallibilizmu lub pierwszych postaci tego poglądu w tym okresie dziejów filozofii.

Fallibilizm nie wymaga od wiedzy pewności (aspekt negatywny), nie mniej jednak zakłada istnienie wiedzy i zarazem ukazuje, że niektóre mniemania są bardziej wiarygodne od innych (aspekt pozytywny). W ten sposób fallibilizm dystansuje się zarówno od dogmatyzmu pozytywnego, jak i od negatywnego dogmatyzmu głoszącego, że wiedza nie istnieje (negatywny dogmatyzm aktualny), lub wiedza nie jest możliwa (negatywny dogmatyzm modalny). Literalnie rzecz biorąc, termin „fallibilizm” wprowadzony do słownika filozoficznego przez Peirce'a pochodzi od łacińskiego przymiotnika fallibilis ${ }^{9}$, który znaczy tyle, co "omylny" (o człowieku), "zwodniczy”, "niepewny”. Warto zauważyć, że wyraz ten można odczytywać na dwa sposoby: (1) akcentując omylność podmiotu poznania i wtedy „być fallible” znaczy, że ktoś jest podatny na bycie zwodzonym lub wprowadzanym w błąd, lub (a nie: albo) (2) akcentując omylność przedmiotu poznania i wtedy "być fallible” znaczy, że coś (przekonanie, doktryna, teoria) jest podatne na bycie błędnym, wątpliwym, niepewnym.

Treść doktryny fallibilizmu sprowadzona do jego etymologii ukazuje wyłącznie tak zwaną negatywną stronę fallibilizmu, która powinna zostać uzupełniona o stronę pozytywną. Dobrym tego przykładem mogą być analizy i typologia teorii wiedzy (w tym: dookreślenie klasy stanowisk fallibilistycznych) w ujęciu Susan Haack, która uważa, że fallibilizm $\mathrm{w}$ najogólniejszym rozumieniu jest po prostu negacją jednej z tez "Czystego Fundacjonalizmu” głoszącej, że "pewne przekonania sa, epistemicznie, całkowicie bezpieczne" (,[s]ome beliefs are, epistemically, absolutely secure"10). Teza ta jest wyrazem niepejoratywnie rozumianego Dogmatyzmu ${ }^{11}$; tak więc w najogólniejszym sensie jest anty-

9 W tym kontekście nie można zapominać o możliwym pochodzeniu łacińskiego fallere od greckiego $\sigma \phi \alpha ́ \alpha \lambda \omega \omega$ ( „przywieść kogoś do upadku”, ,,obalić”, ,,spowodować klęskę", ,zniszczyć”, , złudzić”, ,"zwieść", ,oszukać”” „,być w niepewności”). Jak próbowałem to pokazać wyżej, inne czasowniki greckie mogą oddawać zbliżoną treść do fallere, w tym np. czasownik $\pi \lambda \alpha \dot{\zeta} \omega$.

10 S. Haack, Theories of Knowledge: An Analytic Framework, "Proceedings of the Aristotelian Society, New Series" 1982-1983, vol. 83, s. 144.

11 Zachowuję pisownię określonych terminów z wielkiej lub małej litery, tak jak stosuje to S. Haack i tylko w odniesieniu do jej ustaleń. W jej tekstach zapis taki ma filozoficzne uzasadnienie. Zob. S. Haack, op. cit., s. 150. 
dogmatyzmem przy powyższym rozumieniu Dogmatyzmu. Fallibilizm głosi, że „żadne przekonania nie sa, epistemicznie, całkowicie bezpieczne" (,no beliefs are, epistemically, absolutely secure"12). Zdaniem Haack tak rozumiany fallibilizm (podobnie jak dogmatyzm) to "family of views", a nie pojedyncza teza. W ten sposób do owej "rodziny” należy wiele odmiennych stanowisk; niektórzy nawet twierdza, że współcześnie jest to, jeśli nie jedyna rodzina, to prawdopodobnie najliczniejsza ${ }^{13}$. Susan Haack dokonuje klasyfikacji teorii wiedzy, w której granicznymi stanowiskami są "Czysty Fundacjonalizm” i fallibilistyczny "Czysty Koherencjonizm”, które są ze sobą niezgodne. Pomiędzy nimi jednak zdaniem Haack - znajduje się cały szereg poglądów, a nawet teorii, które można uporządkować ze względu na kryterium Dogmatyzm/ /Fallibilizm, kryterium charakteru uzasadnienia i kryterium epistemicznego egaliteryzmu/epistemicznego nieegalitaryzmu. W ten sposób Haack wyróżnia szereg stanowisk, zarówno dogmatycznych („Nieczysty Fundacjonalizm”), jak i fallibilistycznych („Słaby Fundacjonalizm”, „Foundherentyzm”, "Słaby Koherencjonizm”). Nie wchodząc w szczegóły tych analiz, warto uwzględnić wspomniane kryterium epistemicznego egalitaryzmu do zawężenia zbyt szerokiego zakresowo definiowania fallibilizmu. Mówiąc inaczej, rodzina fallibilizmu tak się rozrosła, że warto $\mathrm{w}$ analizach dokonać jej zawężenia, a więc wskazać - nolens volens arbitralnie - jakieś kryterium wyróżnienia jej właściwego „rdzenia znaczeniowego". Głównym powodem tego zawężenia na potrzeby dalszego wywodu jest klarowne odróżnienie fallibilizmu od sceptycyzmu, a zarazem ukazanie, że fallibilizm oprócz swojej „strony” negatywnej posiada także "stronę" pozytywną.

W ujęciu Haack „Epistemiczny Egalitaryzm” („Epistemic Egalitarianism”) sprowadza się do tezy, w myśl której „żadne przekonanie nie jest, w sobie i przez siebie, epistemicznie bardziej bezpieczne niż jakiekolwiek inne" (,,[n]o belief is, in and of itself, epistemically more secure than any other"14). Z kolei „Epistemiczny Nieegalitaryzm” („Epistemic Inegalitarianism”) jako negacja poprzedniego głosi, że „niektóre przekonania są bardziej bezpieczne od innych" (",some beliefs are more secure than others"15). Kryterium to, z jednej strony, przyzwoicie pozwala odróżnić fallibilizm od sceptycyzmu, który w wersji antycznych sceptyków, np. Pyrrona, czy Sekstusa Empiryka, zakładał negatywnie dogmatyczny „Epistemiczny Egalitaryzm” kulminujący się w koncepcji

12 Ibidem, s. 145.

13 Zdaniem Reeda prawie każda współczesna teoria wiedzy jest jakąś wersją fallibilizmu. Zob. B. Reed, How to Think about Fallibilism, "Philosophical Studies: An International Journal for Philosophy in the Analytic Tradition" 2002, vol. 107, no. 2, s. 143.

14 S. Haack, op. cit., s. 146.

15 Ibidem, s. 148. 


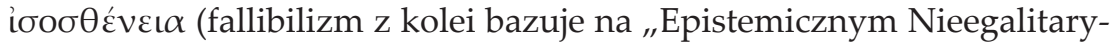

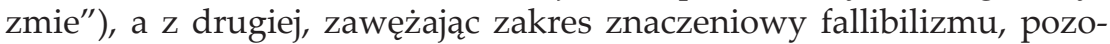
staje bardziej w zgodzie z klasycznymi fallibilistami, to jest $\mathrm{z}$ Peirce'm i Popperem. Przyjmuję zatem, że elementem składowym fallibilizmu po zasadnym zawężeniu jego zakresu znaczeniowego jest „Epistemiczny Nieegalitaryzm” w terminologii Haack, czy też zetetyczny ameinosynkrytycyzm jako forma synkrytycyzmu komparatywnego ${ }^{16}$. W tym wypadku nacisk położony jest na to, że pewne przekonania mogą być

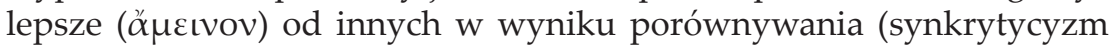
komparatywny), a więc zadaniem filozofii jest ciągłe szukanie (zetetycyzm) lepszych rozwiązań. W kontekście rozważań Haack warto jeszcze zwrócić uwagę na to, że cała gama wyróżnionych przez nią stanowisk łączy wspólne przekonanie, że wiedza istnieje, czy też, że posiadamy wiedzę ${ }^{17}$; wyłączone $\mathrm{z}$ tego zbioru są stanowiska współcześnie określane zbiorczo mianem sceptycyzmu, w myśl których wiedza nie istnieje, czy nawet wiedza nie jest możliwa. $W$ ten sposób fallibilizm będę ujmował jako stanowisko antydogmatyczne i antysceptyczne, ale tylko przy rozumieniu sceptycyzmu jako stanowiska odrzucającego możliwość wiedzy i zlewającego się - przy pewnych wykładniach - z agnostycyzmem jako negatywnym dogmatyzmem. Przyjmuję zatem na potrzeby niniejszego artykułu, że fallibilizm głosi dwie związane ze sobą tezy:

- od strony negatywnej, że „żadne przekonania nie sa, epistemicznie, całkowicie bezpieczne" (,no beliefs are, epistemically, absolutely secure"18);

- od strony pozytywnej, że „niektóre przekonania są bardziej bezpieczne od innych" (,some beliefs are more secure than others" $\left.{ }^{19}\right)$.

Warto jeszcze raz podkreślić, że doktrynę fallibilizmu nie można redukować do maksymy errare humanum est, czy też wyłącznie do podkreślania ludzkiej omylności ${ }^{20}$. Cytowana na początku definicja Ruth Weintraub uzupełnia ten wymiar negatywny („human imperfection”) o wymiar pozytywny („,science and rational inquiry are possible"), który co prawda wystarcza do odróżnienia fallibilizmu od radykalnego scep-

16 Zob. D. Kubok, Comments on the Sources of Greek Philosophical Criticism, "Folia Philosophica", vol. 34. Special issue: Forms of Criticism in Philosophy and Science, ed. by D. Kubok, Katowice 2015, s. 24-25; idem, Xenophanes of Colophon and the problem of distinguishing between scepticism and negative dogmatism, "Electryone" 2016, vol. 4, iss. 2, s. 31-53.

17 Zob. S. Haack, op. cit., s. 144.

18 Ibidem, s. 145.

19 Ibidem, s. 148.

20 Nie można tego czynić, po pierwsze, dlatego, że pominięty zostaje w ogóle aspekt pozytywny fallibilizmu, a po drugie, dlatego, że w ramach aspektu negatywnego akcentuje się tylko omylność podmiotową zapominając o możliwej omylności przedmiotowej. 
tycyzmu (sprowadzającego się współcześnie do tezy: wiedza nie jest możliwa), ale jednocześnie nie uwzględnia kluczowego - w moim przekonaniu - aspektu fallibilizmu, jakim jest zetetyczny ameinosynkrytycyzm, bazujący na epistemicznym nieegalitaryzmie w ujęciu Haack. Nie chodzi zatem tylko o podkreślenie, że wiedza jest możliwa, a nawet, że wiedza istnieje, ale również o akcentowanie procedury ciągłego poszukiwania (zetetycyzm) lepszych (ă $\mu \varepsilon \iota v o v)$ rozwiązań za pomocą metody porównywania, czy też zestawiania ze sobą przekonań (synkrytycyzm komparatywny). To uwypuklenie lepszości i ciagła troska o to, aby szukać tego, co lepsze jeszcze bardziej pogłębia różnice nie tylko między fallibilizmem a radykalnym sceptycyzmem, ale także pomiędzy tak pojmowanym fallibilizmem jako formą ameinosynkrytycyzmu a stanowiskami opierającymi się na epistemicznym egalitaryzmie, do których można zaliczyć radykalny sceptycyzm kulminujący się - tak jak to wi-

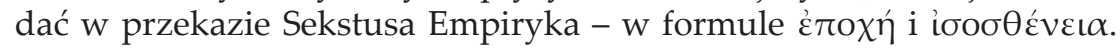
Fallibilizm (przy powyższym rozumieniu) w przeciwieństwie do tak rozumianego sceptycyzmu akcentuje aktywność, a nie bierność, nadzieję, a nie beznadzieję (w zakresie dociekań teoretycznych), prawdopodobną tymczasowość rozwiązań, a nie ich ostateczność, brak pewności, a nie apodyktyczną pewność oraz możliwy postęp w zakresie wiedzy, a nie

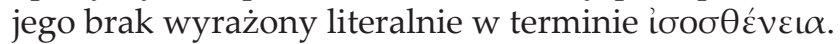

Zadaniem, jakie przed sobą stawiam, jest rozważenie obecności tak rozumianego fallibilizmu $\mathrm{w}$ myśli Ksenofanesa i zdanie sobie sprawy z ograniczeń tego typu poszukiwań antecedencji. Główna nadzieja na ich znalezienie leży $w$ tym, że ten myśliciel działa $w$ okresie, kiedy nie

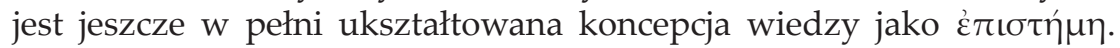
W tym miejscu trzeba również zastrzec, że będę się odnosił do konkretnych fragmentów bez możliwości dokładnej egzegezy każdego z nich, ponieważ przekraczałoby to ramy niniejszego artykułu.

\section{Ksenofanes jako fallibilistyczny argonauta}

Wśród badaczy spuścizny Ksenofanesa istnieje spór dotyczący znaczenia i treści jego fragmentów epistemologicznych ${ }^{21}$. Przede wszystkim przedmiotem dywagacji jest kwestia wątków sceptycznych obecnych $\mathrm{w}$ tych fragmentach. Jednak dopatrywanie się u Ksenofanesa różnych form sceptycyzmu przysłoniło nieco możliwą wykładnię fallibilistyczna, głównie $\mathrm{z}$ tego powodu, że akcentowano przeważnie ludzkie ograniczenia, czy nawet niemożliwości poznawcze we fragmentach kolofończyka, a nie zwracano dostatecznej uwagi na pozytywny wymiar jego wypowiedzi epistemologicznych. $Z$ drugiej jednak strony, za sprawą

21 DK 21 B 18, 21 B 34, 21 B 35, 21 B 36, 21 B 38. 
K. R. Poppera, modelowego fallibilisty, zwolennicy jego wykładni i on sam zaczęli - jeśli można tak powiedzieć - na siłę fallibilizować poglądy Ksenofanesa ${ }^{22}$. Jak w wielu przypadkach, tak i w tej warto zachować właściwą miarę i krytycznie rozważyć możliwość fallibilistycznego odczytania poglądów Ksenofanesa i dopiero wtedy ewentualnie rozważyć jego kandydaturę na fallibilistycznego argonautę.

Należy rozpocząć od fragmentu DK B 34, który w określeniu Leshera (za MacKenzie’ $\mathrm{m}$ ) nazwany być może epistemologicznym „master fragment" 23 .

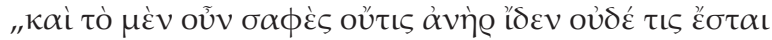

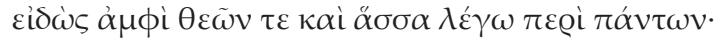

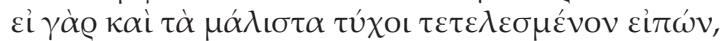

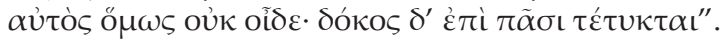

„Zaprawdę jasnej prawdy żaden człowiek nie dostrzegł ani nie będzie nikogo, kto by wiedział o bogach i o tym wszystkim, o czym ja mówię. Gdyby nawet komuś bowiem w najlepszym wypadku udało się powiedzieć to, co spełnione,

sam by o tym nie wiedział; mniemanie ma przynależny udział (we) wszystkim"24.

${ }^{22}$ "And of decisive importance to Western science and philosophy, he [Ksenofanes - D. K.] was the founder of epistemology, the theory of knowledge. [...] I suggest that it was one of Xenophanes' greatest achivements that he anticipated and strongly represented all the main ideas of the European Enlightenment. Among these were the ideas of fighting for truth and against obscurity". K. R. Popper, The World of Parmenides: Essays on the Presocratic Enlightment, London-New York 1998, s. 33-35. Popperowska egzegeza myśli kolofończyka budzi wiele zastrzeżeń filozoficznych i filologicznych. W sprawie polemiki z Popperowską wykładnią myśli Ksenofanesa zob. J. H. Lesher, Xenophanes' Scepticism, "Phronesis” 1978, vol. 23, s. 1-21; S. Austin, Scepticism and Dogmatism in the Presocratics, "Apeiron: A Journal for Ancient Philosophy and Science" 2000, vol. 33, s. 239-246; G. S. Kirk, Popper on Science and the Presocratics, "Mind” 1960, vol. 69, s. 318-339; G. E. R. Lloyd, Popper versus Kirk: A Controversy in the Interpretation of Greek Science, „British Journal for the Philosophy of Science" 1967, vol. 18, s. 21-38. W sprawie nawiązań Poppera do Ksenofanesa zob. R. Attfield, Popper and Xenophanes, "Philosophy" 2014, vol. 89, s. 113-133; D. McDermid, The Gospel of Uncertainty: Popper's Radical Fallibilism Re-Examined, "Grazer Philosophische Studien" 2012, vol. 86, s. 117-119; D. Kubok, Conversation and Conservation. Two Kinds of Anti-Dogmatic Criticism in the Philosophy of Politics and their Antecedents in Ancient Greek Forms of Skepticism and Fallibilism, w: D. Kubok (ed.), Thinking Critically: What Does It Mean? The Tradition of Philosophical Criticism and Its Forms in the European History of Ideas, De Gruyter, Berlin, Boston 2018, s. 88-90.

23 J. H. Lesher, Xenophanes of Colophon: Fragments a Text and Translation with a Commentary, Toronto-Buffalo-London 1992, s. 159.

24 DK 21 B 34. Tłum. własne. 
Sekstus Empiryk, który trzy razy w całości przytacza ten fragment ${ }^{25}$, w swoim komentarzu do niego przywołuje dwie różniące się od siebie interpretacje:

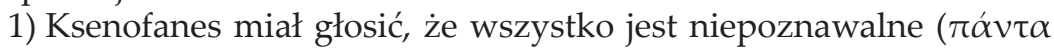

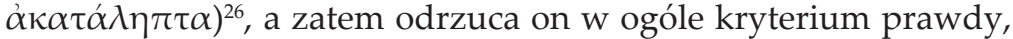
zarówno rozumowe, jak i pozarozumowe ${ }^{27}$. Warto nadmienić, że Sekstus pisze, iż interpretację taką podzielają tylko niektórzy.

2) Ksenofanes nie głosił powszechnej akatalepsji, lecz dopuszczał

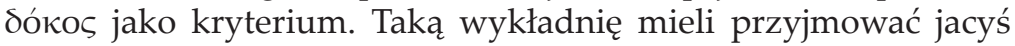

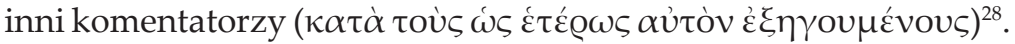

Można powiedzieć, że do dziś wśród badaczy ta Sekstusowa rozbieżność w interpretacji B 34 została zachowana. Nie wchodząc w szczegółową egzegezę tego fragmentu ${ }^{29}$, warto tylko zauważyć, że albo preferuje się pierwszą wykładnię, która prowadzi do agnostycyzmu, czyli do negatywnego dogmatyzmu $\mathrm{w}$ postaci tezy o niepoznawalności ${ }^{30}$, albo drugą otwierającą możliwość odczytania fallibilistycznego. Ktoś mógłby sądzić, że pierwsza wykładnia dotyczy pierwszego zdania fragmentu B 34, druga wykładnia zaś ostatniego. Nic bardziej mylnego. Sekstus, przytaczając pierwszą wykładnię, tę akataleptyczna, w Zarysach pyrrońskich na jej potwierdzenie przytacza tylko ostatni wers fragmentu B 34. Wygląda więc na to, że kluczową sprawą jest klasyfikacja poznawcza kategorii ठókos.

Ogólnie rzecz biorąc, pierwsze zdanie głosi, że nie ma ani nie będzie nikogo, kto by poznał (dostrzegł) tò $\sigma \alpha \phi \varepsilon ́ s$, czyli jasna, wyraźna, dla podmiotu mającą walor pewności prawdę. Trzeba dodać, że w świetle fragm. B 34, 3-4 istnieje możliwość przypadkowego wypowiedzenia jakiejś prawdy bez wiedzy, że się to uczyniło. A zatem tò $\sigma \alpha \phi \varepsilon ́ \varsigma$ nie jest

25 Sext., Adv. math., 7, 49; 7, 110; 8, 326.

26 Sext., Adv. math., 7, 49.

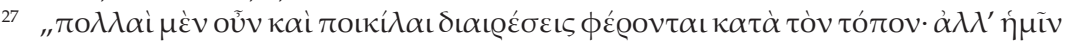

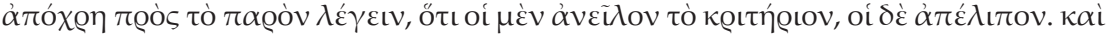

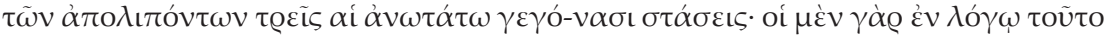

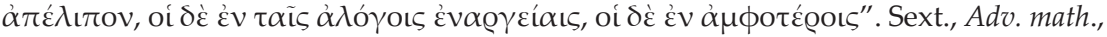
7, 47. W Zarysach pyrrońskich Sekstus również zalicza Ksenofanesa do tych, którzy od-

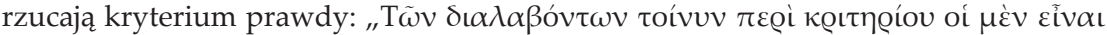

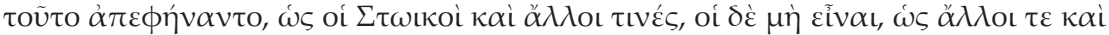

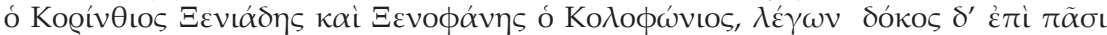

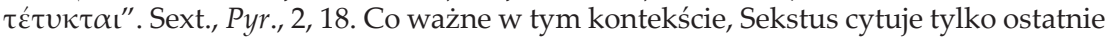
zdanie B 34 .

28 Sext., Adv. math., 7, 110.

29 Zob. D. Kubok, Xenophanes of Colophon and the problem of distinguishing between scepticism and negative dogmatism, op. cit., s. 31-53.

30 Zob. R. Ziemińska, Historia sceptycyzmu, op. cit., s. 35. 
po prostu prawda, tylko prawdą pewna, nieodpartą ${ }^{31}$; i tak rozumiana prawda jest dla człowieka nieosiągalna. Można zatem próbować odczytywać ten fragment jako podważenie możliwości osiągnięcia wiedzy pewnej, co może, choć nie musi prowadzić do koncepcji wiedzy bez pewności, czyli fallibilizmu, jak choćby w definicji Lacey'a ${ }^{32}$. Wsparciem dla takiej wykładni może być pozytywnie interpretowana kategoria ঠóko z ostatniego wersu B 34 oraz druga interpretacja Sekstusa. Nie trzeba wcale przyjmować, że ঠókoৎ ma znaczenie pejoratywne, na przykład $\mathrm{w}$ sensie pozoru, tylko pozytywne jako przekonanie, przypuszczenie. Cały problem interpretacyjny związany jest z tym, do czego się ঠóкo przyrównuje lub od czego się odróżnia, a także perspektywa, która determinuje jego pojmowanie. Jeśli patrzy się na dóko z zerspektywy Ksenofanesowych bogów, czy też Parmenidesowej bogini albo Platońskich idei, to rzecz jasna mniemania będą miały relatywnie negatywną charakterystykę. Jeśli jednak uświadomimy sobie, że tym, co nam pierwotnie jest dane, są nasze ludzkie przekonania odnoszące się do rzeczy da-

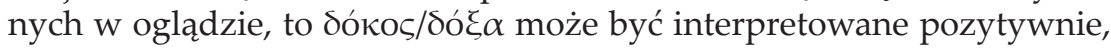
na przykład jako przekonanie bez roszczenia do pewności, ale - o czym jeszcze będzie mowa - z możliwością jego względnej ewaluacji w sensie jego porównywania z innymi. Druga interpretacja Sekstusa nie zakłada akatalepsji, a jako kryterium prawdy ustanawia właśnie ठókos. Zgodnie z nią od wiedzy nie trzeba wymagać pewności, tylko prawdoupodobnienia (wiarygodności) ${ }^{33}$. Takie odczytanie fragm. B 34 pozwalałoby rozpoznać w poglądach Ksenofanesa antecedencje fallibilizmu, szczególnie - o czym dalej - w powiązaniu z fragm. B 18 i B 35. W taki też sposób podsumowuje Sekstus Empiryk drugą wykładnię B 34:

„[...]

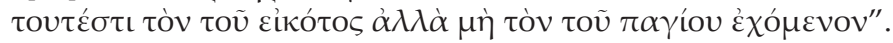

„[...] dlatego kryterium stanowi domniemujący rozum, to znaczy posiadający prawdopodobieństwo, ale nie niewzruszoną pewność" ${ }^{34}$.

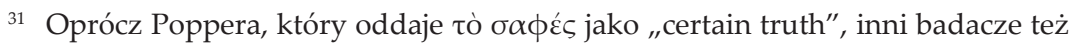
podzielają takie odczytanie. William K. C. Guthrie na przykład również podaje tłumaczenie „certain truth", John Burnet zaś: „,certain knowledge”.

32 Według tego myśliciela fallibilizm jest doktryna, „zgodnie z którą nic lub nic na temat świata nie może być wiadome na pewno albo - alternatywnie - że wiedza nie wymaga tego, aby dowody były logicznie konkluzywne lub całkowicie nie występowało prawdopodobieństwo wystąpienia błędu". A. R. Lacey, Stownik filozoficzny, przeł. R. Matuszewski, Zysk i sp., Poznań 1999.

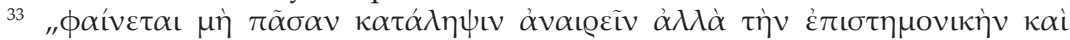

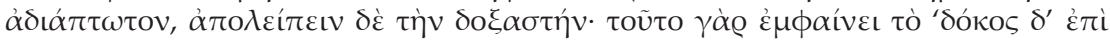

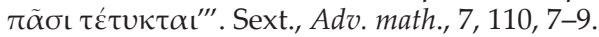

${ }^{34}$ Sext., Adv. math., 7, 110, 10-11. 
Potwierdzenie tej interpretacji można odnaleźć w zachowanym fragm. B 35 Ksenofanesa, w którym pojawiają się słowa: દikós (w for-

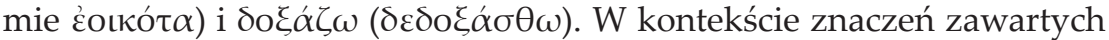

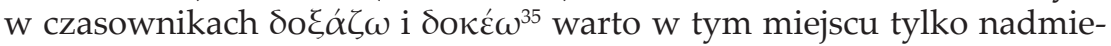
nić, że o ile fragm. B $14^{36}$ Ksenofanesa akcentuje sens negatywny domniemywania jako braku jasności ( $\tau$ ò $\sigma \alpha \phi \varepsilon ́ \varsigma)$, czy też pewności, o tyle B 35 można odczytywać także pozytywnie. Te dwa sensy odpowiadałyby pozytywnemu i negatywnemu określeniu fallibilizmu sformułowanemu powyżej.

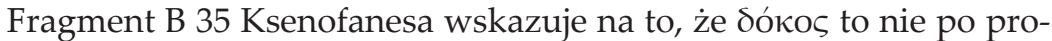
stu ułuda, pozór, a nawet fałsz, lecz przekonanie, które zostaje uznane za podobne prawdzie. Kolejnym krokiem będzie (w B 18) wskazanie na kryterium bycia lepszym, bazujące na założeniu, które współcześnie wykorzystuję tu terminologię Haack - określa się jako Epistemic Inegalitarianism.

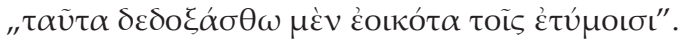

„Te niech są uważane za prawdziwym podobne" ${ }^{\prime 38}$.

Ksenofanes zdaje się sugerować, że poglądy śmiertelnych powinny zostać uznane za podobne do prawdy lub wydają się takimi być, nie mogą bowiem rościć sobie pretensji do pełnej jasności. Decydującą kwe-

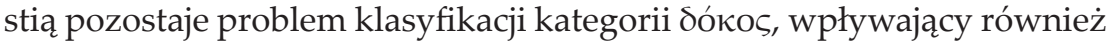
na zagadnienie dotyczące tego, czy zawarta w tym fragmencie rekomendacja ma charakter pozytywny, czy negatywny ${ }^{39}$. Badacze rozpatrują fragm. B 35 zazwyczaj w kontekście stosownych wypowiedzi Homera i Hezjoda:

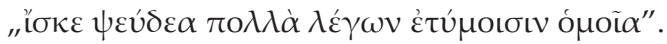

„Wiele zmyślał mówiąc rzeczy do prawdy podobne"40.

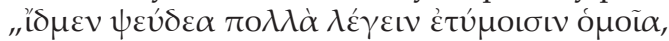

35 S. Śpiewak, The Homeric Source of the Category of $\delta o ́ \xi \alpha$. $\Delta \circ \kappa_{\varepsilon} \omega$ from a CognitivePresumptive Perspective: A Presumption on the Present, "Folia Philosophica” 2015, t. 34, Special issue: Forms of Criticism in Philosophy and Science, ed. by D. Kubok, Katowice 2015, s. 33-60.

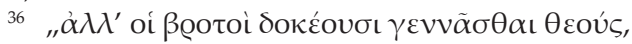

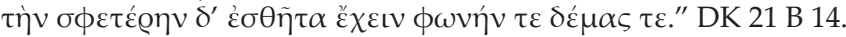

37 Zob. V. Farenga, Open and speak your mind, w: Probabilities, Hypotheticals, and Counterfactuals in Ancient Greek Thought, V. Wohl (ed.), Cambridge University Press, Cambridge 2014, s. 95.

38 DK 21 B 35.

39 Zob. J. H. Lesher, Xenophanes of Colophon: Fragments, op. cit., s. 169-176; E. Heitsch, Das Wissen des Xenophanes, „Rheinisches Museum für Philologie - Neue Folge" 1966, Bd. 109, s. 193-235.

40 Hom., Od., XIX, 203, przeł. J. Parandowski, w: Homer, Odyseja, Warszawa 1998. 


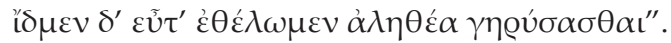

„Wiemy, jak głosić kłamstwa liczne do prawdy podobne, wiemy też gdy, zechcemy, jak rzeczy prawdziwe obwieszczać" ${ }^{41}$.

Trzeba zauważyć, że u Ksenofanesa homerowo-hezjodowa fra-

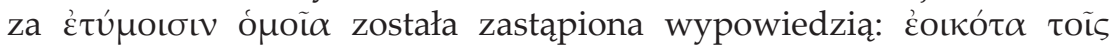

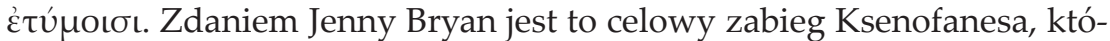
ry ma ukazać odmienne rodzaje podobieństwa do prawdy niż te, które nawiązują do wypowiedzi Muz lub Odyseusza ${ }^{42}$. Muzy mogą wypowiadać zarówno kłamstwa do prawdy podobne, jak i rzeczy prawdziwe, posiadają bowiem taką umiejętność i wiedzę. Ważne jest jednak to, że z perspektywy człowieka ta ich umiejętność przekłada się na ludzką niezdolność odróżnienia tych kłamstw od prawdy. Taka wykładnia podkreśla nie tylko boską zwodniczość przekazu, ale także ludzką bezradność w rozpoznawaniu prawdy, a więc ma wymiar negatywny. Ksenofanesowa zmiana terminologii podkreśla zmianę formuły podobieństwa, a także klasyfikacji jakościowej tego, co jest do prawdy podobne. J. Bryan uważa, że ó $\mu$ oio ukazuje obiektywny charakter podobieństwa, natomiast દ̇oık $\omega \varsigma \varsigma$ wyraża bardziej subiektywne, potencjalnie zwodnicze podobieństwo ${ }^{43}$. Można przyjąć, że Ksenofanes chce podkreślić, iż od strony podmiotowej nasze przekonania, choć nie mają waloru pewności, to jednak są podobne do prawdy, możemy je traktować jako „możliwą, lecz niepewną prawdę"44. Dodatkowo trzeba podkreślić fakt, że Ksenofanes traktuje swoje wypowiedzi ani nie jako nieprawdziwe, ani nie jako prawdziwe, lecz raczej jako takie, które mogą być prawda, przy jednoczesnym braku wiedzy o tym z jakąkolwiek pewnością. Odczytanie takie

${ }^{41}$ Hesiod, Theog., 27-28, w: Hezjod, Narodziny bogów (Theogonia), Prace i dni, Tarcza, przeł. J. Łanowski, Warszawa 1999.

${ }_{42}$ J. Bryan, Likeness and Likelihood in the Presocratics and Plato, Cambridge Classical Studies, Cambridge University Press, Cambridge, New York 2012, s. 12-16.

43 Zob. J. Bryan, Likeness and Likelihood..., op. cit., s. 30 i 45-48. Warto nadmienić,

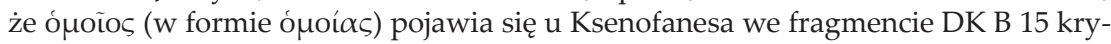
tykującym potencjalny zoomorfizm, a także we fragmencie B 23, w którym Ksenofa-

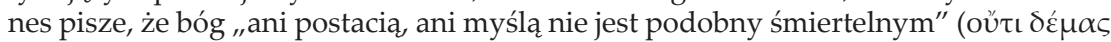

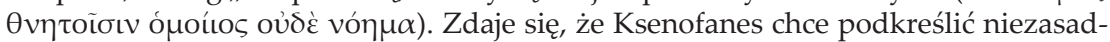
ność przy-równywania ludzkich wyobrażeń bogów do nich samych. W kwestii interpretacji fragmentów teologicznych kolofończyka zob. D. Kubok, Ksenofanes z Kolofonu i greckie źródła problemu poznania, „Analiza i Egzystencja” 2013, nr 23, ss. 5-23. Z kolei

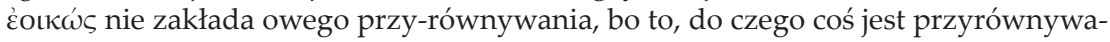
ne, pozostaje nieokreślone; można $\mathrm{w}$ takim przypadku mówić tylko o potencjalnym podobieństwie wynikającym nie z wiedzy o obu członach zrównywanych rzeczy, ale tylko o domniemaniach podmiotu.

44 J. Bryan, Likeness and Likelihood..., op. cit., s. 46. Badaczka ta stwierdza ostatecznie, że B 35 można przełożyć zarówno w sensie instruktywnym (Let these [teachings] be believed to be like the truth), jak i klasyfikującym (These [teachings] have been believed to be like the truth). Zob. ibidem, s. 55 . 
skłania Bryan do opowiedzenia się za fallibilistyczną interpretacją B 35 Ksenofanesa ${ }^{45}$. Problem jednak $\mathrm{w}$ tym, że badaczka ta, nie dookreślając rozumienia fallibilizmu, wiąże fallibilizm ze stanowiskiem, które określa jako „epistemic pessimism”"46. Wydaje się, że taka opinia związana jest $\mathrm{z}$ dopatrywaniem się $\mathrm{w}$ fallibilizmie głównie aspektu negatywnego bez rozpoznania jego strony pozytywnej, która tkwi nie tylko w B 35, ale także w B 18 oraz we fragmentach elegijnych.

Wykładnia fallibilistyczna poglądów Ksenofanesa w aspekcie negatywnym znajduje swoje odzwierciedlenie $w$ doksografii zaświadczającej o tym, że jasna (wyraźna) prawda, czyli tò $\sigma \alpha \phi \varepsilon ́ \varsigma$ (opierająca się na pewności) przysługiwać może tylko bogom (bogu), śmiertelnym zaś taka prawda nie jest dana (element negatywny), ale mogą oni posiadać ठókoı prawdzie podobne, choć potencjalnie (a nie aktualnie) fałszywe. Takie świadectwa można odnaleźć u Arejosa Didymosa i Warrona, którzy w kontekście poglądów Ksenofanesa piszą o przeciwstawieniu boskiej

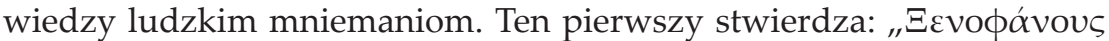

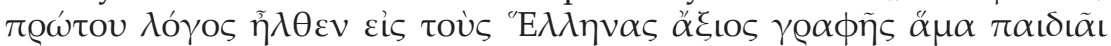

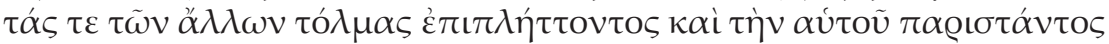

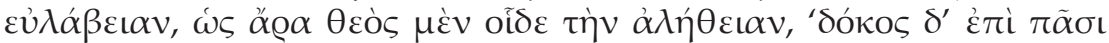

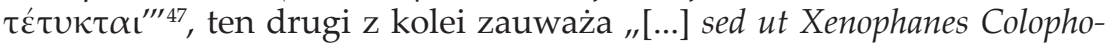
nios scribit, quid putem, non quid contendam, ponam. Hominis est enim haec opinari, dei scire" ${ }^{\prime 48}$. Święty Augustyn w tym ostatnim fragmencie opozycję pomiędzy ludźmi a bogiem opiera na przeciwstawieniu przypuszczenia (domniemania) pewności.

Z kolei w aspekcie pozytywnym wykładnia fallibilistyczna może być wsparta egzegezą fragm. B 18 oraz fragmentami elegijnymi Ksenofanesa. Jak już była o tym mowa, ten pozytywny aspekt fallibilizmu wyraża się w formule głoszącej, że niektóre przekonania są bardziej bezpieczne od innych. Ta zasada epistemicznego nieegalitaryzmu (Haack) akcentuje po prostu sceptyczne w sensie źródłowym, to znaczy zetetyczne poszukiwanie tego, co lepsze. Ksenofanes wyraża ją we fragm. B 18:

45 Zob. ibidem, s. 48-55.

46 Ibidem, s. 48.

47 Arius Didymus ap. Stob., Ecl. II, 1, 17 (DK 21 A 24). Ostatnie zdanie fragm. B 34

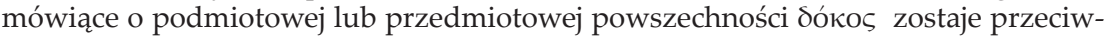

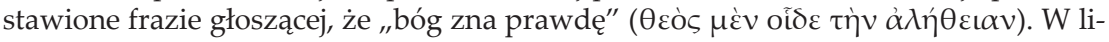
teraturze istnieje spór dotyczący przełożenia $\pi \tilde{\alpha} \sigma \iota$ we fragm. B 34, 4. Słowo to można w grece traktować zarówno w rodzaju męskim jak i nijakim; w zależności od przyjętej opcji ঠókoৎ odnosi się do wszystkich (podmiotowo) lub do wszystkiego (przedmiotowo). Asekuracyjnie zakładam, że istnieją argumenty za obiema możliwościami,

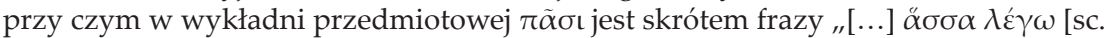
Ksenofanes] $\pi \varepsilon \varrho i$ $\pi \alpha ́ v \tau \omega \nu^{\prime \prime} \mathrm{z}$ wersu drugiego, a nie po prostu „wszystkiego”.

48 Varro ap. Augustinus, De civ. dei, VII, 17. 


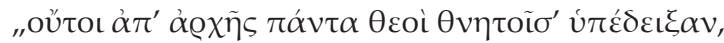

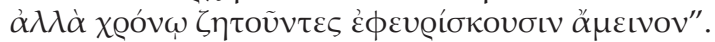

"Zaiste nie od razu wszystko bogowie śmiertelnym ujawnili, lecz z czasem, szukający znajdują to, co lepsze ${ }^{\prime 49}$.

Fragment ten jest w literaturze przedmiotem szczegółowych analiz ${ }^{50}$, $\mathrm{w}$ tym miejscu warto skupić się tylko na zasadzie poszukiwania tego, co lepsze, mając świadomość tego, że w zależności od położenia akcentów, na różne sposoby można to zdanie interpretowaćs1. Uszczegóławiając to zagadnienie, da się wyróżnić trzy pary przeciwstawnych elementów

49 DK 21 B 18, tłum. własne.

50 W kwestii interpretacji tego fragmentu, a w szczególności odnośnie do dość powszechnej interpretacji „progresywnej” zob. np. J. H. Lesher, Xenophanes on Inquiry and Discovery: An Alternative to the 'Hymn to Progress.' Reading of Fr. 18, "Ancient Philosophy" 1991, vol. 11, s. 229-248; A. Tulin, Xenophanes Fr. 18 D.-K. and the Origins of the Idea of Progress, "Hermes" 1993, vol. 121, s. 129-138; J. H. Lesher, Xenophanes of Colophon: Fragments, op. cit., s. 150-155, W. J. Verdenius, Xenophanes Frag. 18, "Mnemosyne" 1955, vol. 8, s. 221; J. H. M. M. Loenen, In Defence of the Traditional Interpretation of Xenophanes Frag. 18, "Mnemosyne" 1956, vol. 9, s. 135-136; P. Shorey, Note on Xenophanes Fr. 18 (Diels) and Isocrates Panegyricus 32, "Classical Philology" 1911, vol. 6, no. 1, s. 88-89; D. Kubok, Postęp, pycha, pokora: Ksenofanes z Kolofonu a Hezjod, „Folia Philosophica" 2014, nr 32, s. 215-231.

51 „Fragment 18 charakteryzuje się specyficzną budowa, która wyznacza dwa możliwe kierunki jego interpretacji. Wers pierwszy przeciwstawiony jest wersowi

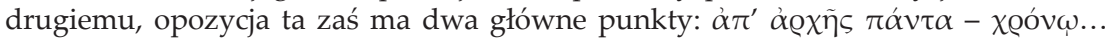

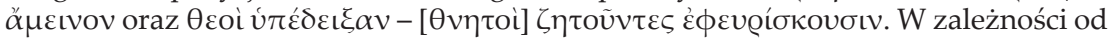
tego, którą z tych par uzna się za dominująca, fragment zyska nieco odmienną wymowę". M. Marcinkowska, Ksenofanes z Kolofonu o ludzkim poznaniu, „Studia Antyczne i Mediewistyczne" 2004, nr 2 [37], s. 15. Dobrym przeglądem dyskusyjnych zagadnień $\mathrm{i}$ alternatyw egzegetycznych $\mathrm{w}$ tym fragmencie jest artykuł J. H. Leshera pod tytułem Xenophanes on Inquiry and Discovery: An Alternative to the 'Hymn to Progress' Reading of Fr. 18, w którym autor wyróżnia następujące trudności: I.1: (akcent pada na $\dot{\alpha} \pi^{\prime} \dot{\alpha} \varrho \chi \tilde{\eta} \varsigma$ ) bogowie nie ujawnili wszystkiego „na początku”, lub „od razu” może

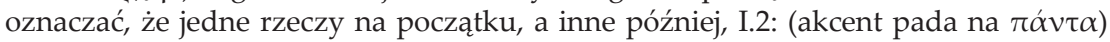
czy bogowie nie ukazali wszystkiego od początku - jest to aspekt kwantytatywny, I.3: (akcent pada na oútoı $\left.\dot{\alpha} \pi^{\prime} \dot{\alpha} \varrho \chi \tilde{\eta} \varsigma\right)$ czy ewentualnie fraza „nie od początku” może oznaczać ",nigdy”; II: czy bogowie pomagają szukającym, czy ci ostatni szukają na własną rękę (w tym miejscu warto nadmienić, że dla Greków nie ma sprzeczności $\mathrm{w}$ stwierdzeniu o samodzielnym poszukiwaniu z jednoczesnym traktowaniem bogów jako darczyńców ludzi); III: w odniesieniu do zdania drugiego można wyróżnić cztery alternatywy, III.1: śmiertelni znajdują lepiej i lepsze rzeczy cały czas, III.2: śmiertelni znajdują coś lepszego niż to, co wiedzieli w przeszłości, III.3: śmiertelni znajdują coś lepszego niż to, co bogowie rzekomo im ujawnili, III.4: dzięki szukaniu

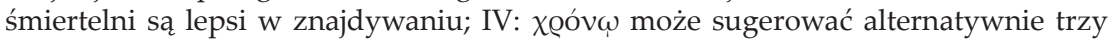
opcje, IV.1: śmiertelni dość długo znajdują lepiej, IV.2: śmiertelni, gdy długo szukaja, to znajdują lepiej, IV.3: w jakimś dowolnym czasie po początku śmiertelni znajdują lepiej przez szukanie. Szerzej na temat alternatyw wyróżnionych przez Leshera zob. D. Kubok: Postęp, pycha, pokora, op. cit., s. 221-225. 
(pierwszy człon jest w każdym przypadku z wersu pierwszego, drugi z drugiego) i jedną triadę:

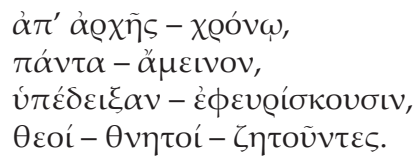

Z punktu widzenia poszukiwania argumentów za fallibilistycznym odczytaniem poglądów Ksenofanesa najważniejszą tezą jest stwierdzenie, że bogowie nie wszystko od razu ludziom ujawnili, lecz że szukający znajdują to, co lepsze, lub znajdują lepiej (są lepsi w znajdywaniu) ${ }^{52}$. $\mathrm{Z}$ tego wynika, że nie tylko pewna wiedza nie jest dana człowiekowi (B34,1-2), ale także wiedza pełna, przynajmniejod razu. Kluczowąjednak sprawą w perspektywie wyróżnionego wyżej pozytywnego aspektu fal-

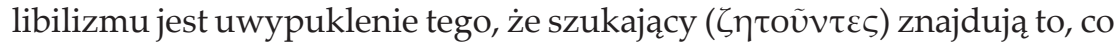
lepsze (ă $\mu \varepsilon เ v o v)$. Stwierdzenie to jest wyrazem synkrytycyzmu komparatywnego $\mathrm{w}$ formule ameinosynkrytycyzmu zetetycznego ${ }^{53}$, chodzi bo-

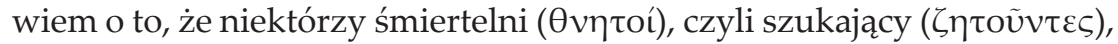
nie czekają biernie na boskie dary poznawcze, jak inni śmiertelni, lecz

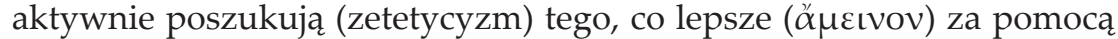
procedury porównywania (synkrytycyzm komparatywny). W ten sposób filozofię Ksenofanesa można wyrazić jako ameinosynkrytycyzm zetetyczny, którego jedną z form może być fallibilizm w jego aspekcie pozytywnym. W ten sposób widać jasno dwie rzeczy: 1) Ksenofanesowy ameinosynkrytycyzm zetetyczny, bazujący na epistemicznym nieegalitaryzmie, daje się wyrazić $\mathrm{w}$ formie fallibilizmu; natomiast nie wydaje się możliwy do pogodzenia z odczytaniem radykalnie sceptycznym

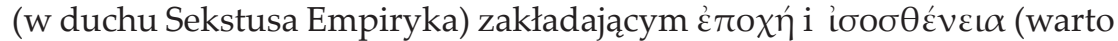

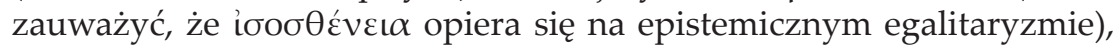
2) z tego względu druga wykładnia fragm. B 34 sformułowana przez Sekstusa Empiryka wydaje się bardziej zasadna w kontekście fragmentów B 35 i B 18.

Podstawowym problemem $\mathrm{w}$ perspektywie możliwego fallibilistycznego odczytania ameinosynkrytycyzmu zetetycznego Ksenofanesa jest wskazanie na kryterium bycia lepszym. W zachowanych fragmentach kolofończyka takich wskazówek wprost odnaleźć nie można, ale

52 Słowo ånعıvov można odczytywać jako przymiotnik w stopniu wyższym albo jako przysłówek. Za tą drugą propozycją optuje James Lesher, który interpretuje końcową frazę B $34 \mathrm{w}$ sensie: ,'they discover in a better way' or 'they do better at discovering"'. J. H. Lesher, Xenophanes on Inquiry and Discovery, op. cit., s. 246.

53 John Philippoussis nazywa metodę Ksenofanesa "the zetetic hypotheticocomparative logic". J. Philippoussis, The Gnoseological and Metaphysical Particularity of Xenophanes' Thought, w: Boudouris K. J. (ed.), Ionian Philosophy, Athens 1989, s. 332. 
da się przywołać przynajmniej dwa przykłady, w których widać zastosowanie procedury poszukiwania tego, co lepsze; tylko w pierwszym $\mathrm{z}$ nich pojawia się słowo $\dot{\alpha} \mu \varepsilon i ́ v \omega v$.

„[...] $\varrho^{\prime} \omega \mu \eta \varsigma \gamma \gamma \dot{\alpha} \varrho \alpha \dot{\alpha} \mu \varepsilon \dot{v} v \omega \nu$

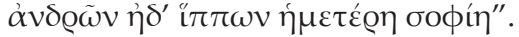

„[...] bo lepsza od siły mężów oraz koni jest nasza mądrość' ${ }^{54}$.

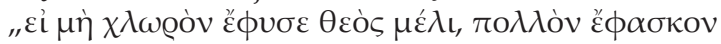
$\gamma \lambda \hat{\sigma} \sigma \sigma o v \alpha \sigma \tilde{\kappa} \kappa \alpha \pi \varepsilon \dot{\lambda} \varepsilon \sigma \theta \alpha \iota^{\prime \prime}$.

„Gdyby bóg nie stworzył żółtego miodu, sądziliby, że figi są o wiele słodsze" ${ }^{\prime \prime 55}$.

Nie wchodząc w szczegółową analizę każdego z tych fragmentów, trzeba tylko zauważyć, że w obu przypadkach kryterium bycia lepszym ma charakter pragmatyczny, a nie ściśle teoretyczny. Ksenofanes za-

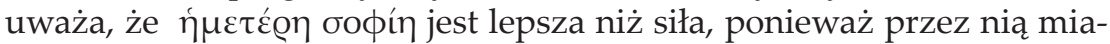
sto staje się bardziej sprawiedliwe. W tej elegii kryterium ma charakter etyczno-polityczny. Drugi natomiast fragment, który można traktować jako rozwinięcie egzemplifikacyjne fragm. B 18, podkreśla bezzasadność rozstrzygnięć ostatecznych, kumulujących się w pozornym przeświad-

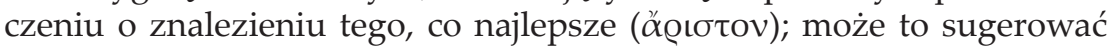
zasadność ciągłego poszukiwania tego, co lepsze (tutaj: tego, co słodsze). Kwestią otwartą pozostaje problem istnienia i ewentualnego określenia teoretycznego kryterium „lepszości” w filozofii Ksenofanesa ${ }^{56}$. W tym miejscu wystarczy tylko skonstatować, że samo wskazanie na zetetycznie ujętą zasadę ameinosynkrytycyzmu wzmacnia wykładnię fallibilistyczną myśli Ksenofanesa kosztem wykładni sceptycznej (agnostycystycznej).

\section{Historycznofilozoficzny fallibilizm w stylu Ksenofanesa}

Za prekursora fallibilizmu ${ }^{57}$ badacze uważają zazwyczaj Karneadesa. W moim przekonaniu jest to o tyle wątpliwe, że myśliciel ten zakłada

54 DK 21 B 2, 11-12; tłum. własne.

55 DK 21 B 38; tłum. własne.

56 Gdyby uzupełnić powyższe rozważania o egzegezę fragmentu B 36 („ó $\pi \pi$ ó $\sigma \alpha$

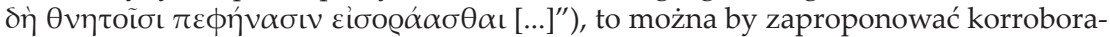
cyjne odczytanie poglądów Ksenofanesa. Można też po prostu to ciągłe poszukiwanie tego, co lepsze rozumieć nie w tym sensie, że gromadzi się - kumulatywnie - coraz więcej wiedzy (doświadczeń), lecz, że - krytycznie - coraz więcej można odrzucić ze względu na niespełnianie kryterium lepszości.

57 Zob. N. Rescher, Fallibilism, w: The Routledge Encyclopedia of Philosophy, E. Craig (ed.), Vol. I-X, Routledge, London-New York 1998. 


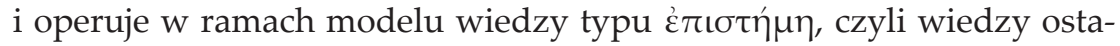
tecznej i pewnej. Więcej nawet, sceptycy greccy od Pyrrona do Sekstusa ten model wiedzy respektują. Mówiąc metaforycznie, wszyscy oni próbują płynąć przez cieśninę Skylli i Charybdy. Można jednak przyjąć, że właściwych historycznofilozoficznych źródeł fallibilizmu trzeba szukać

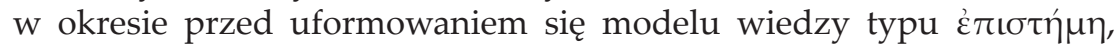
godząc się na model wiedzy bez pewności, tymczasowej (a nie ostatecznej) i hipotetycznej (potencjalnie fałszywej). Trzeba szukać wśród tych, którzy płynęli jeszcze drogą (lub widzieli taką możliwość) przez „błądzące skały” ( $\pi \lambda \alpha \gamma \kappa \tau \alpha \grave{\imath} \pi \varepsilon ́ \tau \varrho \alpha \iota)$. Poglądy Ksenofanesa zrodziły się w momencie, w którym jeszcze nie ukształtował się model wiedzy

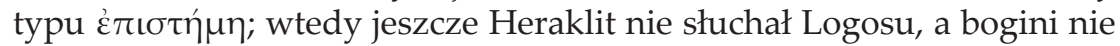
ukazała młodzieńcowi drogi prawdy, o czym wspomina Parmenides. Wymienione powyżej argumenty sprzyjają upatrywaniu w Ksenofanesie fallibilistycznego argonauty. W jego fragmentach można odnaleźć przede wszystkim koncepcję wiedzy doksalnej (druga wykładnia B 34 w ujęciu Sekstusa) zamiast wiedzy z roszczeniem do ostatecznej pewności, a także argumenty przychylające się do odczytania fallibilistycznego jego koncepcji, i to zarówno w negatywnym, jak i pozytywnym aspekcie pojmowania fallibilizmu.

Jednak aby być w zgodzie z krytycystycznym modelem umysłowości kolofończyka, trzeba także zdawać sobie sprawę z argumentów przeciwko takiej wykładni. Dopiero wtedy zrealizuje się krytyczny model fallibilistyczny na poziomie historycznofilozoficznym. Przede wszyst-

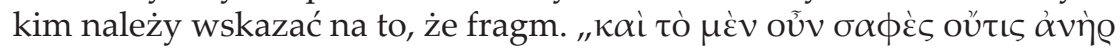

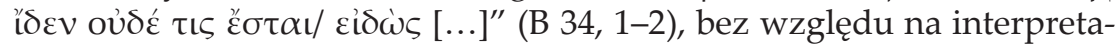

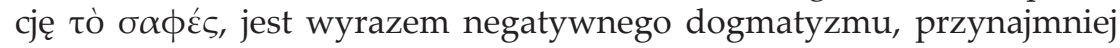
$\mathrm{W}$ tej części, która dogmatycznie wypowiada się na temat przyszłego stanu naszej wiedzy ${ }^{58}$. Sam fragment B 34 bez komentarza Sekstusa (jego druga wykładnia $)^{59}$ jest mało fallibilistyczny, przede wszystkim jednak

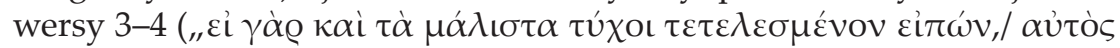

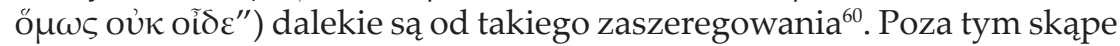
źródła nie pozwalają wskazać na kryterium bycia lepszym, a nawet na udowodnienie, że kryterium takie mogło mieć zastosowanie ściśle teoretyczne. Niewykluczone jest również, że kryterium takie miało charakter przede wszystkim pragmatyczny, a domniemany fallibilizm Ksenofa-

58 W kontekście tego argumentu można by rozważyć, czy nie jest tak, że fallibilizm jako taki, jako rodzina poglądów, nie zakłada negatywnego dogmatyzmu pod postacią tezy o niemożliwości istnienia wiedzy pewnej. Kontrargumentem zapewne może być stwierdzenie, że według fallibilizmu nasze przekonania są tylko potencjalnie fałszywe.

59 Sext., Adv. math., 7, 110, 10-11.

60 Zob. J. H. Lesher, Xenophanes of Colophon: Fragments, op. cit., s. 164-165. 
nesa był tylko lokalny, tak jak lokalny był jego negatywny dogmatyzm

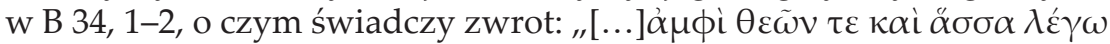

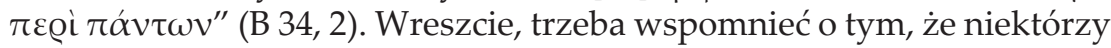
badacze na siłę fallibilizują poglądy Ksenofanesa, traktując je jako antycypację ich pomysłów (Popper), inni z kolei uznają za niedopuszczalne poszukiwanie antecedencji współczesnych doktryn w myśli greckiej.

Nie można zatem jednoznacznie rozstrzygnąć tego, czy Ksenofanes był fallibilistycznym argonautą bo będąc w zgodzie z doktryną fallibilizmu, nikt od nas nie wymaga wiedzy pewnej. Ewentualna odpowiedź na postawione wyżej pytanie też nie jest całkowicie bezpieczna. Zamiast rozstrzygania tej kwestii można poprzestać na historycznofilo-

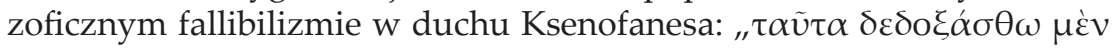

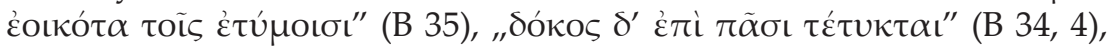

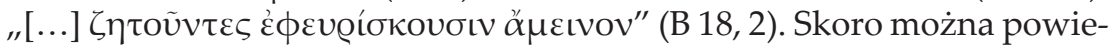
dzieć, że miód jest słodszy niż figi (B 38), to można też powiedzieć, że wydaje się $e^{61}$, iż Ksenofanes mógł być fallibilistycznym argonauta a tym samym może uchodzić za tego, który wcześniej niż Karneades (a być może i w większym stopniu) płynął przez "błądzące skały” ( $\pi \lambda \alpha \gamma \kappa \tau \alpha i$

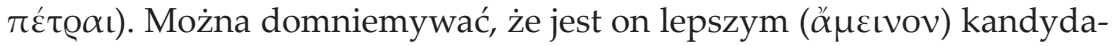
tem na prekursora fallibilizmu.

Roberto Calasso pisze: „Z biegiem czasu staje się coraz bardziej zrozumiałe, dlaczego najwięksi herosi tak zdecydowanie i tak uparcie dążą do wtajemniczenia, jak Herakles i Dioskurowie w Eleusis, jak wszyscy Argonauci na wyspie Samotrake: wiedza, że brakuje im czegoś istotnego, rozumieja że nie są doskonali" ${ }^{\prime 2}$. Ksenofanes jako kandydat na fallibilistycznego argonautę jest inny, nie dąży uparcie do wtajemniczenia (jak Parmenides czy Empedokles), ale głęboko rozumie konsekwencje niedoskonałości swojej i innych. Uświadomienie sobie tej niedoskonałości wiąże się z rozpoznaniem ludzkich ograniczeń poznawczych i z pogodzeniem się z omylnością człowieka, która prowadzi do pokory, ale nie do rezygnacji i bierności charakterystycznej dla agnostycyzmu jako negatywnego dogmatyzmu. Krytyczna pokora zmusza człowieka do poszukiwania i doceniania lepszych rozwiązań, a nie beznadziejnego uganiania się za tym, co ostateczne, niepodważalne i najlepsze. Filozoficzny heroizm Ksenofanesa pozwala mu być pełnym nadziei argonauta, który pogodził się z faktem, że może nie odnaleźć Złotego Runa.

61 Inny myśliciel joński z tego samego okresu dziejów, Hekatajos z Miletu miał

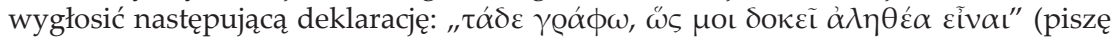
to, co wydaje mi się, że jest prawdą). Demetr. Rhet., De eloc., 12, 8-19.

62 R. Calasso, Zaślubiny Kadmosa z Harmonia, przeł. S. Kasprzysiak, Znak, Kraków 1995, s. 324. 


\section{Bibliografia}

Attfield R., Popper and Xenophanes, „Philosophy” 2014, vol. 89, s. 113-133.

Austin S., Scepticism and Dogmatism in the Presocratics, "Apeiron: A Journal for Ancient Philosophy and Science" 2000, vol. 33, s. 239-246.

Bryan J., Likeness and Likelihood in the Presocratics and Plato, Cambridge Classical Studies, Cambridge University Press, Cambridge, New York 2012.

Calasso R., Zaślubiny Kadmosa z Harmonia, przeł. S. Kasprzysiak, Znak, Kraków 1995.

Die Fragmente der Vorsokratiker. Griechisch und Deutch, von H. Diels, hrsg. von W. Kranz, Bd. 1-3, Zürich 1985.

Farenga V., Open and speak your mind, w: Probabilities, Hypotheticals, and Counterfactuals in Ancient Greek Thought, V. Wohl (ed.), Cambridge University Press, Cambridge 2014, s. 84-100.

Haack S., Theories of Knowledge: An Analytic Framework, "Proceedings of the Aristotelian Society, New Series" 1982-1983, vol. 83, s. 143-157.

Hanuszewicz S., Znaczenie fallibilizmu, http://zbc.uz.zgora.pl/Content/3012/ fallibilizm_calosc.pdf, data wejścia: 29.12.2017.

Havelock E. A., Parmenides and Odysseus, „Harvard Studies in Classical Philology" 1958, vol. 63, s. 133-143.

Heitsch E., Das Wissen des Xenophanes, „Rheinisches Museum für Philologie - Neue Folge" 1966, Bd. 109, pp. 193-235.

Hezjod, Narodziny bogów (Theogonia), Prace i dni, Tarcza, przeł. J. Łanowski, Warszawa 1999.

Homer, Odyseja, przeł. i oprac. J. Parandowski, Warszawa 1998.

Kirk G. S., Popper on Science and the Presocratics, „Mind” 1960, vol. 69, s. 318-339 .

Kubok D., Comments on the Sources of Greek Philosophical Criticism, „Folia Philosophica" 34. Special issue: Forms of Criticism in Philosophy and Science, ed. by D. Kubok, Katowice 2015, s. 9-31.

Kubok D., Conversation and Conservation. Two Kinds of Anti-Dogmatic Criticism in the Philosophy of Politics and their Antecedents in Ancient Greek Forms of Skepticism and Fallibilism, w: D. Kubok (ed.), Thinking Critically: What Does It Mean? The Tradition of Philosophical Criticism and Its Forms in the European History of Ideas, De Gruyter, Berlin, Boston 2018, s. 73-92.

Kubok D., Ksenofanes z Kolofonu i greckie źródła problemu poznania, "Analiza i Egzystencja" 2013, nr 23, s. 5-23.

Kubok D., Postep, pycha, pokora: Ksenofanes z Kolofonu a Hezjod, „Folia Philosophica" 2014, nr 32, s. 215-231.

Kubok D., Xenophanes of Colophon and the problem of distinguishing between scepticism and negative dogmatism, "Electryone” 2016, vol. 4, iss. 2, s. 31-53.

Lacey A. R., Słownik filozoficzny, przeł. R. Matuszewski, Zysk i sp., Poznań 1999. 
Lesher J. H., Xenophanes on Inquiry and Discovery: An Alternative to the 'Hymn to Progress.' Reading of Fr. 18, "Ancient Philosophy” 1991, vol. 11, s. 229$-248$.

Lesher J. H., Xenophanes of Colophon: Fragments. A Text and Translation with a Commentary by J. H. Lesher, Toronto 1992.

Lesher J. H., Xenophanes' Scepticism, „Phronesis” 1978, vol. 23, s. 1-21.

Lloyd G. E. R., Popper versus Kirk: A Controversy in the Interpretation of Greek Science, „British Journal for the Philosophy of Science” 1967, vol. 18, s. 21-38.

Loenen J. H. M. M., In Defence of the Traditional Interpretation of Xenophanes Frag. 18, „Mnemosyne” 1956, vol. 9, s. 135-136.

Marcinkowska M., Ksenofanes z Kolofonu o ludzkim poznaniu, "Studia Antyczne i Mediewistyczne" 2004, nr 2 [37], s. 3-25.

McDermid D., The Gospel of Uncertainty: Popper's Radical Fallibilism Re-Examined, „Grazer Philosophische Studien” 2012, vol. 86, s. 117-136.

Mourelatos A. P. D., The Route of Parmenides, Yale University Press, New Haven-London 1970.

Popper K. R., The World of Parmenides: Essays on the Presocratic Enlightment, London-New York 1998.

Philippoussis J., The Gnoseological and Metaphysical Particularity of Xenophanes' Thought, w: Boudouris K. J. (ed.), Ionian Philosophy, Athens 1989, s. 327-336.

Reed B., How to Think about Fallibilism, „Philosophical Studies: An International Journal for Philosophy in the Analytic Tradition" 2002, vol. 107, no. 2, 143-157.

Rescher N., Fallibilism, w: The Routledge Encyclopedia of Philosophy, E. Craig (ed.), vol. I-X, : Routledge, London-New York 1998.

Sextus Empiricus, Adversus mathematicos, w: Sexti Empirici Opera. Rec. H. Mutschmann. II Adversus dogmaticos libros quinque (Adv. Math. VII-XI) continens. Lipsiae, in Aedibus B. G. Teubneri 1914; III Adversus mathematicos libros I-VI continens, ed. J. Mau, Lipsiae, in Aedibus B. G. Teubneri 1961.

Sextus Empiricus, Outlines of Pyrrhonism, R. G. Bury (trans.), Prometheus Books, Buffalo 1990.

Shorey P., Note on Xenophanes Fr. 18 (Diels) and Isocrates Panegyricus 32, "Classical Philology" 1911, vol. 6, no. 1, s. 88-89.

Śpiewak S., The Homeric Source of the Category of $\delta o ́ \xi \alpha$. $\Delta$ oké $\omega$ from a CognitivePresumptive Perspective: A Presumption on the Present, „Folia Philosophica" 34. Special issue: Forms of Criticism in Philosophy and Science, ed. by D. Kubok, Katowice 2015, s. 33-60.

Tulin A., Xenophanes Fr. 18 D.-K. and the Origins of the Idea of Progress, „Hermes” 1993, vol. 121, s. 129-138.

Verdenius W. J., Xenophanes Frag. 18, „Mnemosyne” 1955, vol. 8, s. 221.

Weintraub R., Fallibilism and Rational Belief, "The British Journal for the Philosophy of Science" 1993, vol. 44, iss. 2, s. 251-261.

Ziemińska R., Historia sceptycyzmu, Toruń 2013. 


\section{Streszczenie}

Artykuł stawia sobie za cel rozważenie filozofii Xenophanesa w perspektywie wykładni fallibilistycznej. W pierwszej kolejności trzeba omówić ogólnie stanowisko fallibilizmu i dookreślić jego rozumienie. W tym zakresie zostaną przeanalizowane wybrane definicje fallibilizmu ze szczególnym uwzględnieniem badań nad tą doktryną dokonanych przez Susan Haack. Wyróżniony zostanie pozytywny i negatywny aspekt fallibilizmu. Zasadniczym zadaniem w tym opracowaniu będzie przeanalizowanie kluczowych z punktu widzenia epistemologicznego fragmentów Xenophanesa pod kątem możliwego odczytania fallibilistycznego, zarówno w wyróżnionym aspekcie pozytywnym, jak i negatywnym fallibilizmu. Ukazane zostaną również argumenty za odczytaniem jego filozofii w duchu antyfallibilistycznym. Wreszcie, zgodnie z pozytywnym aspektem fallibilizmu odniesionego do rozważań historycznofilozoficznych, postaram się pokazać, że poglądy Xenophanesa w większym stopniu niż późniejsze wypowiedzi Karneadesa nadają się na uznanie ich za historyczne źródła fallibilizmu.

Słowa kluczowe: fallibilizm, Ksenofanes, sceptycyzm, epistemologia, wiedza

\section{Summary}

\section{Beyond Scylla and Charybdis. The Problem of Fallibilist Interpretations of Xenophanes' Thought}

In this article, I examine extant fragments of works by Xenophanes from the perspective of fallibilist interpretations. I begin with a general description of the fallibilist position and specify how fallibilism may be understood. To this end, I analyze select definitions of fallibilism with special attention paid to Susan Haack's research on this doctrine. A distinction between positive and negative fallibilism is also introduced. The main aim of the article is to analyze key epistemological fragments by Xenophanes in the context of a possible fallibilist interpretation, from the perspective of both, positive and negative forms of fallibilism distinguished earlier. I will also present arguments for interpreting his philosophy in the spirit of anti-fallibilism. Finally, I will try to show that Xenophanes' views, to a greater degree than the later Carneades views, are apt to be recognized as the historical source of positive fallibilism.

Keywords: fallibilism, Xenophanes, skepticism, epistemology, knowledge 